\title{
Prognostic implication of human papillomavirus types in cervical cancer patients: a systematic review and meta- analysis
}

Yuanyuan Xu', Yichao Qiu', Shuang Yuan ${ }^{1}$ and Hongjing Wang ${ }^{2^{*}}$

\begin{abstract}
Background: To estimate the prognostic relevance of human papillomavirus (HPV) 16 and HPV 18 in patients with cervical cancer.

Method: We searched PubMed, EMBASE, American Society of Clinical Oncology (ASCO) and the European Society of Medical Oncology (ESMO), CNKI, and Wanfang databases to search primary articles illustrating the survival outcomes in cervical cancer patients with or without HPV 16/18 infection. A meta-analysis was conducted to generate a combined hazard ratio (HR) with 95\% confidence intervals (Cl) for progression-free survival (PFS), disease free survival (DFS) and overall survival (OS).

Results: A total of 13 studies were included. Our meta-analysis revealed that HPV 16 positive did not have any impact on OS (HR, 0.76; 95\% Cl=0.37-1.54; $P=0.44)$. Cervical cancer patiensts infected with HPV 18 had worse OS $(\mathrm{HR}, 1.66 ; 95 \% \mathrm{Cl}=1.28-2.17 ; P=0.0001), \mathrm{DFS}(\mathrm{HR}, 2.10 ; 95 \% \mathrm{Cl}=1.73-2.54 ; P<0.0001)$ and worse PFS $(\mathrm{HR}, 2.97 ; 95 \%$ $\mathrm{Cl}=1.69-5.23 ; P=0.00012)$ compared with those not infected with HPV 18. cervical cancer patiensts infected with HPV 18 had worse PFS compared with those infected with HPV $16((\mathrm{HR}, 1.34 ; 95 \% \mathrm{Cl}=1.06-1.70 ; P=0.01)$.

Conclusion: Cervical cancer patients infected with HPV 18 had worse survival compared with cervical cancer patients with HPV 16 infection.
\end{abstract}

Keywords: Human papillomavirus 16, Human papillomavirus 18, Survival, Cervical cancer

\section{Background}

Cervical cancer occurs in the cells of the cervix, with highest incidence rates found among women between 40 and 60 years old. Cervical cancer is the second most common female cancer worldwide [1]. The prevalance of cervical cancer is 4640 per 100,000 people according to the European standard population, with a relative 5-

\footnotetext{
* Correspondence: whjscdx@163.com

${ }^{2}$ Department of Obstetrics and Gynecology, West China Second University Hospital, Sichuan University, No.20, Section 3, South People's Road, Chengdu, Sichuan, P.R. China

Full list of author information is available at the end of the article
}

year-survival rates of $68 \%$ [2]. Approximately twelve high risk genotypes of the human papillomavirus (HPV) play a role in the development of cervical cancer. Nowdays, many countries have introduced HPV vaccine to reduce HPV infection and the risk to develop cervical cancer. HPV 16 and HPV 18 are the most common genotypes identified in cervical carcinoma, representing $70 \%$ of all infections [3]. Among these two genotypes, HPV 16 is the most common genotype worldwide found in patients with invasive cervical cancer. The prevalance of HPV 16 infection ranged from 42 to $75 \%$ [4-8], followed by HPV 18 with a prevalance of 10 to $30 \%$ [4, 8-13]. HPV 16

C C The Author(s). 2020 Open Access This article is licensed under a Creative Commons Attribution 4.0 International License, which permits use, sharing, adaptation, distribution and reproduction in any medium or format, as long as you give appropriate credit to the original author(s) and the source, provide a link to the Creative Commons licence, and indicate if changes were made. The images or other third party material in this article are included in the article's Creative Commons licence, unless indicated otherwise in a credit line to the material. If material is not included in the article's Creative Commons licence and your intended use is not permitted by statutory regulation or exceeds the permitted use, you will need to obtain permission directly from the copyright holder. To view a copy of this licence, visit http://creativecommons.org/licenses/by/4.0/ The Creative Commons Public Domain Dedication waiver (http://creativecommons.org/publicdomain/zero/1.0/) applies to the data made available in this article, unless otherwise stated in a credit line to the data. 
and HPV 18 are among the genotypes (HPV 16, 18, 31, $33,35,45,52$ and 58) which are strongly associated with progression to cervical cancer compared with other high risk genotypes and low risks genotypes [14, 15]. High risk genotypes include HPV 16, 18, 31, 33, 35 39, 45, 51, $52,56,58,59,68,73$ and 82 . Low risk genotypes include HPV 6, 11, 40, 42, 43, 44, 54, 61, 70, 72 and 81, which are associated with benign lesions $[16,17]$.

Several factors would impact the prognosis for cervical cancer patients, such as tumor staging, size and metastatis. Although the effect of HPV on the development of cervical cancer has been well eastablished, its function of prognosis is still not well understood. Several studies have found the prognosis role of HPV 18 infections in early stage cervical cancer patients $[10,11,18]$. Several studies have found that patients diagnosed with early stage cervical cancer and infected by HPV 18 have worse prognosis. A retrospective study including 116 cervical cancer patients which received primary surgical treatment showed that positivity for HPV 18 was associated with shorter progression free survival (PFS) (HR: 5.2, 95\% $\mathrm{CI}=1.29-20.9, P=0.02$ ) [8]. Another populationbased study with 24,041 women also found that HPV 18 infection was an independent prognostic factor for 3year survival in cervical cancer (HR: 1.704, 95\% CI = 1.095-2.654) [13]. However, controversy still exists regarding the prognostic relevance of HPV 18 in patients with cervical cancer. A study with 236 stage I-III Chinese cervical cancer patients aged 26 to 87 years after receiving primary treatment proved that HPV 18 did not have significant impact on disease free survival (DFS) (hazard ratio (HR): $1.49,95 \%$ confidence interval $(\mathrm{CI})=$ $0.78-2.86)$ or overall survival (OS) (HR: $1.23,95 \% \mathrm{CI}=$ 0.66-2.27) [4]. A brazil cohort study conducted with 86 stage I cervical cancer patients found that the presence of HPV 18 would not affect DFS (HR: $0.797,95 \% \mathrm{CI}=$ $0.175-3.640)$ [9].

The prognostic impact of HPV 16 on survival in patients with cervical cancer is also controversial $[4-7,9]$. Although these studies suggested no significant impact of HPV infection on DFS or PFS, its significance on OS did not reach consistency. A Chinese study consisting 306 cervical cancer patients found that presence of HPV 18 was negatively associated with OS (HR: 0.36, 95\% $\mathrm{CI}=0.18-0.74, P=0.005)$ [5]. A Korea study consisting 298 patients I-V stage cervical cancer patients also proved the significant relevance of HPV 18 on OS (HR: 0.558, 95\% CI $=0.326-0.955, P=0.033$ ) [6]. However, other studies proved that HPV 16 was not a prognoctic factor for OS in cervical cancer patients. Yat Ming Lau and collegues found that presence of HPV 18 was not significant for OS in patients with stage I-III cervical cancer (HR: 0.99, 95\% CI =0.64-1.55). A Japanese study consisting 137 stage I-IV cervical cancer also found no survival relevance of HPV 18 infection (HR: 0.42, 95\% $\mathrm{CI}=0.15-1.04, P=0.06)$ [7]. However, to date, no previous study published the systematic review and meta analysis of impact of HPV on survival in cervical cancer patients.

Thus, we performed an updated systematic review and meta-analysis to summarize the impact of HPV 16 and HPV 18 on survival in patients with cervical cancer.

\section{Methods \\ Literature search}

PubMed, EMBASE, American Society of Clinical Oncology (ASCO) and the European Society of Medical Oncology (ESMO), CNKI, and Wanfang databases were searched by our researchers using common keywords related to HPV 16, HPV 18, cervical cancer and survival. The following keywords were included: human papillomavirus 16, human papillomavirus 18, cervical cancer, DFS, PFS and OS. We reviewed the details of these relevant publications for additional papers.

\section{Selection criteria}

We selected articles that met the following criteria: (1) the clinical study recruited patients with pathologically or cytologically diagnosed cervical cancer; (2) the clinical study investigated survival related results, such as PFS, DFS and OS with a HR and 95\% CI.

\section{Study results extraction}

Two independent researchers in our department read all the publications independently and discussed the study extraction until they reached consensus. The criterias defined by Cochrane Handbook for Systematic Reviews of Interventions version 5.1.0 were used [19], the following six domains were assessed: (1) randomization generation, (2) allocation concealment, (3) participants and personnel blinding, (4) outcome assessment blinding, (5) incomplete outcome data, (6) reporting selective outcome. Data obtained from the studies included the author, year of publication, patient source (region), age of patients, number of patients and survival outcomes.

\section{Statistical analysis}

We chose PFS, DFS and OS as the endpoints in our meta-analysis. The survival data associated with HPV 16 and HPV 18 were summarized in Tables 1, 2 and 3. HR and $95 \%$ CI were used as measures of the prognostic value using Review Manager (RevMan) Version 5.4, for Windows. Publication bias was evaluated according to the funnel plot and Begg's and Egger's tests. Statistical heterogeneity was calculated using the Chi-square test and also calculation of the $\mathrm{I}^{2}$ statistic. We considered an $\mathrm{I}^{2}$ value $>50 \%$ to indicate a significant heterogeneity between these studies. A random effects model was used if 
Table 1 Study characteristics of studies investigating the prognostic relevance of HPV-16

\begin{tabular}{|c|c|c|c|c|c|c|c|c|c|c|c|}
\hline Author & Year & Country & $\begin{array}{l}\text { Total } \\
\text { number } \\
\text { of } \\
\text { patients }\end{array}$ & $\begin{array}{l}\text { Mean } \\
\text { age }\end{array}$ & $\begin{array}{l}\text { Clinical } \\
\text { stage }\end{array}$ & Treatment & $\begin{array}{l}\text { Number } \\
\text { of } \\
\text { patients } \\
\text { with } \\
\text { HPV-16 } \\
\text { positive }\end{array}$ & $\begin{array}{l}\text { Number } \\
\text { of } \\
\text { patients } \\
\text { with } \\
\text { HPV-18 } \\
\text { negative }\end{array}$ & $\begin{array}{l}\text { Median } \\
\text { DFS }\end{array}$ & $\begin{array}{l}\text { Median } \\
\text { PFS }\end{array}$ & Median OS \\
\hline $\begin{array}{l}\text { Yat Ming } \\
\text { Lau }\end{array}$ & 2015 & $\begin{array}{l}\text { Hong } \\
\text { Kong, } \\
\text { China }\end{array}$ & 236 & 54.4 & $|-|||$ & $\begin{array}{l}\text { radiotherapy+/ } \\
\text {-chemotherapy }\end{array}$ & 142 & 94 & $\begin{array}{l}73.2 \% \text { vs. } \\
81.2 \% \\
\text { HR: } 1.54 \\
95 \% \mathrm{Cl}= \\
0.93-2.56\end{array}$ & NA & $\begin{array}{l}71.6 \% \text { vs. } \\
81.7 \% \\
\text { HR: } 0.99 \\
95 \% \mathrm{Cl}= \\
0.64-1.55\end{array}$ \\
\hline $\begin{array}{l}\text { Dong } \\
\text { Hang }\end{array}$ & 2017 & China & 306 & 48 & I-IV & $\begin{array}{l}\text { surgery alone, surgery plus } \\
\text { adjunctive chemotherapy, } \\
\text { radiotherapy or } \\
\text { chemoradiotherapy, } \\
\text { concurrent } \\
\text { chemoradiotherapy, } \\
\text { chemotherapy or radiotherapy } \\
\text { only. }\end{array}$ & 186 & 120 & NA & NA & $\begin{array}{l}\text { HR: } 0.36,95 \% \\
C l=0.18-0.74 \\
P=0.005\end{array}$ \\
\hline $\begin{array}{l}\text { Mamiko } \\
\text { Onuki }\end{array}$ & 2018 & Japan & 137 & 49.2 & I-IV & Surgery+radiotherapy & 59 & 78 & NA & NA & $\begin{array}{l}\text { HR: } 0.42, \\
95 \% \mathrm{Cl}= \\
0.15-1.04 \\
P=0.06\end{array}$ \\
\hline $\begin{array}{l}\text { Byoung } \\
\text { Hyuck Kim }\end{array}$ & 2019 & Korea & 298 & 48 & I-IV & radiotherapy & 164 & 127 & NA & $\begin{array}{l}77.6 \text { vs. } \\
57.7 \% \\
P=0.022\end{array}$ & $\begin{array}{l}\text { HR: } 0.558 \\
95 \% \mathrm{Cl}= \\
0.326- \\
0.955, P=0.033\end{array}$ \\
\hline $\begin{array}{l}\text { Sun-Hye } \\
\text { Yang }\end{array}$ & 2014 & Korea & 116 & NA & $|-| \mid A$ & surgery & 49 & 67 & NA & $\begin{array}{l}\text { HR: } 1.33, \\
95 \% \\
\mathrm{Cl}= \\
0.31- \\
5.67 \\
P=0.70\end{array}$ & Not significant \\
\hline $\begin{array}{l}\text { Rossana de } \\
\text { Araú jo } \\
\text { Catão } \\
\text { Zampronha }\end{array}$ & 2013 & Brazil & 86 & 40 & I & Surgery+radiotherapy & 30 & 56 & $\begin{array}{l}\text { HR: } 1.104 \\
95 \% \mathrm{Cl}= \\
0.243- \\
5.007\end{array}$ & NA & NA \\
\hline
\end{tabular}

HPV Human papillomavirus, DFS Disease free survival, HR Hazard ratio, CI Confidence interval, NA Not available, DFS Disease free survival, PFS Progression free survival, OS Overall survival

significant heterogeneity was detected among studies. If $\mathrm{I}^{2}$ value was below $50 \%$, results were measured using a fixed effects model.

\section{Results}

Study characteristics of the recruited studties

In total, 13 eligible studies were included in this systematic review and meta-analysis, with 6 trials about the survival data of cervical cancer patients infected with HPV 16 and 7 trials about the survival data of cervical cancer infected with HPV 18. Among these publications, 3 publications investigated the impact of both HPV 16 and HPV 18 on survival in cervical cancer patients. Three publications investigated the impact of both HPV 16 and HPV 18 on survival in cervical cancer patients. A flow chart of selection of the studies is illustrated in Fig. 1. Tables 1, 2 and 3 summarize the basic characteristics of the included studies of HPV 16 and HPV 18, including name of the first author, publication country, publication year, treatment, age of patients, clinical stage of tumor, number of patients infected with or without HPV, median DFS, median PFS and median OS. All 13 studies met the allocation concealment.

\section{Meta-analysis of survival outcome Studies regarding the prognoctic relevance of HPV 16 on OS}

We identified 4 eligible trials [4-7] including 977 cervical cancer patients, and investigated OS following HPV 16 positive versus HPV 16 negative patients. Our metaanalysis revealed that HPV 16 positive did not have any impact on OS (HR, 0.76; 95\% CI $=0.37-1.54 ; P=0.44$, Fig. 2).

\section{Studies regarding the prognoctic relevance of HPV 18 on \\ OS}

We identified 4 eligible trials $[4,9,11,13]$ including 25 , 635 cervical cancer patients, and investigated OS following HPV 16 positive versus HPV 18 negative patients. Our meta-analysis revealed that cervical cancer patiensts 
Table 2 Study characteristics of studies investigating the prognostic relevance of HPV-18

\begin{tabular}{|c|c|c|c|c|c|c|c|c|c|c|c|}
\hline Author & Year & Country & $\begin{array}{l}\text { Total } \\
\text { number } \\
\text { of } \\
\text { patients }\end{array}$ & $\begin{array}{l}\text { Mean } \\
\text { age }\end{array}$ & $\begin{array}{l}\text { Clinical } \\
\text { stage }\end{array}$ & Treatment & $\begin{array}{l}\text { Number } \\
\text { of } \\
\text { patients } \\
\text { with } \\
\text { HPV-18 } \\
\text { positive }\end{array}$ & $\begin{array}{l}\text { Number } \\
\text { of } \\
\text { patients } \\
\text { with } \\
\text { HPV-18 } \\
\text { negative }\end{array}$ & $\begin{array}{l}\text { Median } \\
\text { DFS }\end{array}$ & $\begin{array}{l}\text { Median } \\
\text { PFS }\end{array}$ & $\begin{array}{l}\text { Median } \\
\text { OS }\end{array}$ \\
\hline $\begin{array}{l}\text { Yat Ming } \\
\text { Lau }\end{array}$ & 2015 & $\begin{array}{l}\text { Hong } \\
\text { Kong, } \\
\text { China }\end{array}$ & 236 & 54.4 & $|-|||$ & radiotherapy+/-chemotherapy. & 30 & 185 & $\begin{array}{l}73.2 \% \text { vs. } \\
78.2 \%, \mathrm{HR}: \\
1.49,95 \% \\
\mathrm{Cl}=0.78- \\
2.86\end{array}$ & NA & $\begin{array}{l}80 \% \text { vs. } \\
75.7 \%, \mathrm{HR} \\
1.23,95 \% \\
\mathrm{Cl}=0.66- \\
2.27\end{array}$ \\
\hline $\begin{array}{l}\text { Sun-Hye } \\
\text { Yang }\end{array}$ & 2014 & Korea & 116 & NA & I-IIA & surgery & 15 & 101 & NA & $\begin{array}{l}\text { HR: } 5.2 \\
95 \% \\
\mathrm{Cl}= \\
1.29- \\
20.9, P= \\
0.02\end{array}$ & $\begin{array}{l}\text { Not } \\
\text { significant }\end{array}$ \\
\hline $\begin{array}{l}\text { Rossana de } \\
\text { Araú jo } \\
\text { Catão } \\
\text { Zampronha }\end{array}$ & 2013 & Brazil & 86 & 40 & 1 & Surgery+radiotherapy & 25 & 51 & $\begin{array}{l}\text { HR: } 0.797, \\
95 \% \mathrm{Cl}= \\
0.175- \\
3.640\end{array}$ & NA & NA \\
\hline $\begin{array}{l}\text { Robert A. } \\
\text { Burger }\end{array}$ & 1996 & USA & 291 & NA & I-IV & $\begin{array}{l}\text { radical hysterectomy and } \\
\text { pelvic lymphadenectomy }\end{array}$ & 58 & 233 & NA & NA & $\begin{array}{l}\text { HR: } 2.59 \\
95 \% \mathrm{Cl}= \\
1.08-6.22\end{array}$ \\
\hline $\begin{array}{l}\text { Chyong- } \\
\text { Huey Lai }\end{array}$ & 2007 & $\begin{array}{l}\text { Taiwan, } \\
\text { China }\end{array}$ & 1067 & 50 & $|A-| \mid A$ & surgery & 176 & 891 & $\begin{array}{l}\text { HR: } 1.8, \\
95 \% \mathrm{Cl}= \\
1.8-2.7\end{array}$ & & $\begin{array}{l}\text { HR: } 1.7 \\
95 \% \mathrm{Cl}= \\
1.1-2.6\end{array}$ \\
\hline $\begin{array}{l}\text { Woo Dae } \\
\text { Kang }\end{array}$ & 2011 & Korea & 204 & 49 & $\mid \mathrm{B}-\| \mathrm{A}$ & $\begin{array}{l}\text { radical hysterectomy followed by } \\
\text { adjuvant radiotherapy or primary } \\
\text { radiotherapy with concurrent } \\
\text { cisplatin-containing } \\
\text { chemotherapy }\end{array}$ & 28 & 176 & NA & $\begin{array}{l}\text { HR: } \\
2.664 \\
95 \% \\
\mathrm{Cl}= \\
1.437- \\
4.938\end{array}$ & NA \\
\hline $\begin{array}{l}\text { Shizhuo } \\
\text { Wang }\end{array}$ & 2012 & China & 24,041 & NA & I-IV & NA & 2082 & 21,959 & NA & NA & $\begin{array}{l}\text { HR: } 1.704, \\
95 \% \mathrm{Cl}= \\
1.095- \\
2.654\end{array}$ \\
\hline
\end{tabular}

HPV Human papillomavirus, DFS Disease free survival, HR Hazard ratio, Cl Confidence interval, NA Not available, DFS Disease free survival, PFS Progression free survival, OS Overall survival

Table 3 Study characteristics of studies investigating the prognostic relevance of HPV-16 and HPV-18

\begin{tabular}{|c|c|c|c|c|c|c|c|c|c|c|c|}
\hline Author & Year & Country & $\begin{array}{l}\text { Total } \\
\text { number } \\
\text { of } \\
\text { patients }\end{array}$ & $\begin{array}{l}\text { Mean } \\
\text { age }\end{array}$ & $\begin{array}{l}\text { Clinical } \\
\text { stage }\end{array}$ & Treatment & $\begin{array}{l}\text { Number of } \\
\text { patients with } \\
\text { HPV-16 positive }\end{array}$ & $\begin{array}{l}\text { Number of } \\
\text { patients with } \\
\text { HPV-18 positive }\end{array}$ & $\begin{array}{l}\text { Median } \\
\text { DFS }\end{array}$ & $\begin{array}{l}\text { Median } \\
\text { PFS }\end{array}$ & $\begin{array}{l}\text { Median } \\
\text { OS }\end{array}$ \\
\hline Mi Chen & 2019 & China & 131 & $29-61$ & $|-|||$ & $\begin{array}{l}\text { adjuvant } \\
\text { radiation }\end{array}$ & 88 & 19 & $\begin{array}{l}\text { HR: 1.13, } \\
95 \% \mathrm{Cl}= \\
0.78-1.64\end{array}$ & NA & $\begin{array}{l}\text { HR: } 1.39, \\
95 \% \mathrm{Cl}= \\
1.14-1.69\end{array}$ \\
\hline $\begin{array}{l}\text { Yuanyuan } \\
\text { Wang }\end{array}$ & 2018 & China & 232 & NA & $|-|||$ & $\begin{array}{l}\text { adjuvant } \\
\text { radiation }\end{array}$ & 108 & 19 & NA & $\begin{array}{l}\text { Not } \\
\text { significant }\end{array}$ & $\begin{array}{l}\text { HR: 2.17, } \\
95 \% \mathrm{Cl}= \\
1.20-3.92\end{array}$ \\
\hline $\begin{array}{l}\text { Ruihong } \\
\text { Lan }\end{array}$ & 2017 & China & 40 & 40.21 & $\|-\mid\|$ & $\begin{array}{l}\text { adjuvant } \\
\text { radiation }\end{array}$ & 22 & 10 & NA & NA & $\begin{array}{l}\text { HR: } 1.15, \\
95 \% \mathrm{Cl}= \\
1.01-1.31\end{array}$ \\
\hline
\end{tabular}



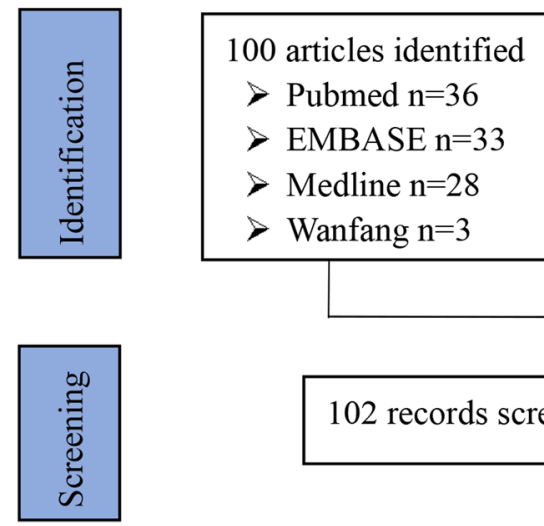

2 records identified

through hand

searching of

references in relevant

systematic reviews
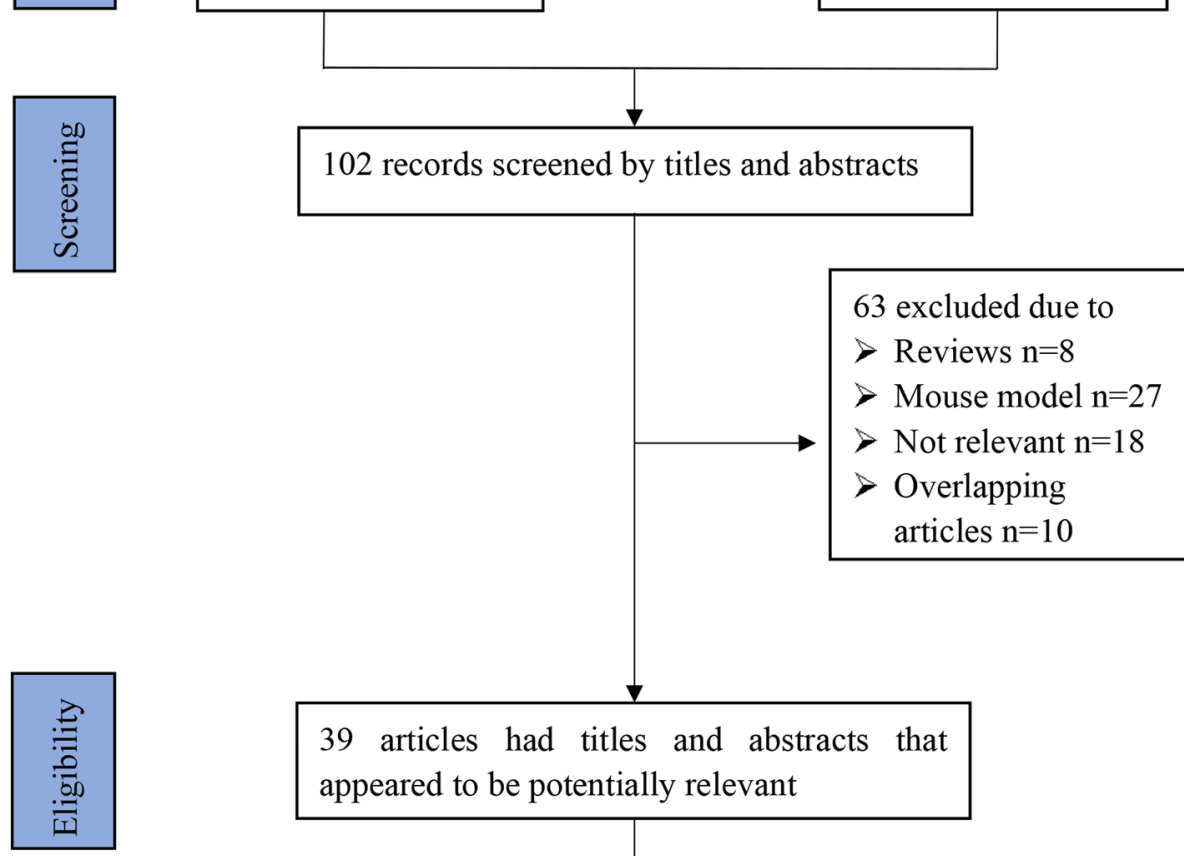

39 articles had titles and abstracts that appeared to be potentially relevant
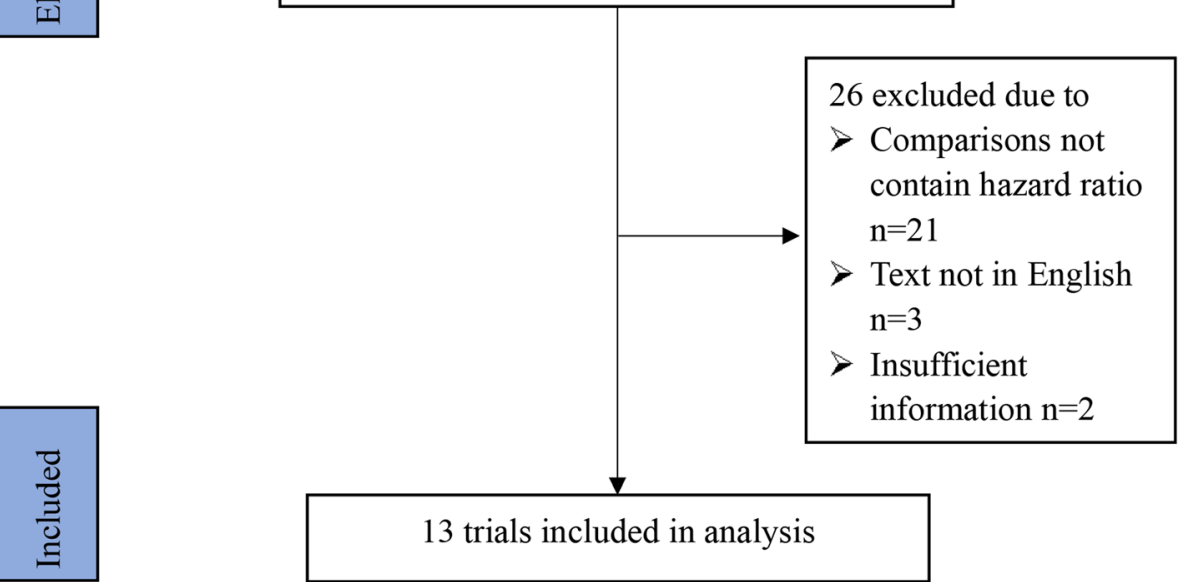

Fig. 1 Flowchart of computerized search and the eligible studies included in this systematic review and meta-analysis

infected with HPV 16 had worse OS compared with those not infected with HPV 18 (HR, 1.66; 95\% CI = 1.28-2.17; $P=0.0001$, Fig. 3).

\section{Studies regarding the prognoctic relevance of HPV 18 on DFS}

We identified 3 eligible trials [4, 9, 11] including 1389 cervical cancer patients, and investigated DFS following HPV 18 positive versus HPV 18 negative patients. Our meta-analysis revealed that cervical cancer patiensts infected with HPV 18 had worse DFS compared with those not infected with HPV 18 (HR, 2.10; 95\% CI = 1.73-2.54; $P<0.0001$, Fig. 4).

\section{Studies regarding the prognoctic relevance of HPV 18 on PFS}

We identified 2 eligible trials [8, 12] including 320 cervical cancer patients, and investigated PFS following HPV 18 positive versus HPV 18 negative patients. Our meta-analysis revealed that cervical cancer patiensts infected with HPV 18 had worse PFS compared with those 


\begin{tabular}{|c|c|c|c|c|c|}
\hline Study or Subgroup & log[Odds Ratio] & SE & Weight & $\begin{array}{c}\text { Odds Ratio } \\
\text { IV. Random, } 95 \% \mathrm{Cl}\end{array}$ & $\begin{array}{c}\text { Odds Ratio } \\
\text { IV. Random, } 95 \% \mathrm{Cl}\end{array}$ \\
\hline Byoung Hyuck Kim 2019 & -0.0101 & 0.2226 & $28.6 \%$ & $0.99[0.64,1.53]$ & \\
\hline Dong Hang 2017 & -1.008 & 0.3606 & $24.3 \%$ & $0.36[0.18,0.74]$ & \\
\hline Mamiko Onuki 2018 & -0.9289 & 0.494 & $20.1 \%$ & $0.39[0.15,1.04]$ & \\
\hline Yat Ming Lau 2015 & 0.5835 & 0.2742 & $27.1 \%$ & $1.79[1.05,3.07]$ & \\
\hline Total $(95 \% \mathrm{Cl})$ & & & $100.0 \%$ & $0.76[0.37,1.54]$ & \\
\hline \multicolumn{5}{|c|}{$\begin{array}{l}\text { Heterogeneity: } \text { Tau }^{2}=0.41 ; \mathrm{Chi}^{2}=15.53, \mathrm{df}=3(P=0.001) ; \mathrm{I}^{2}=81 \% \\
\text { Test for overall effect: } Z=0.76(P=0.44)\end{array}$} & $\begin{array}{lllll} & 1 & 1 & + \\
0.02 & 0.1 & 1 & 10 & 50 \\
\text { Favours HPV16+ } & \text { Favours HPV16- }\end{array}$ \\
\hline
\end{tabular}

not infected with HPV 18 (HR, 2.97; 95\% CI = 1.69-5.23; $P=0.00012$, Fig. 5).

\section{Studies regarding the prognoctic relevance of HPV 18 in comparision with HPV 16}

We identified 3 eligible trials [20-22] including 403 cervical cancer patients, and investigated OS following HPV 18 positive versus HPV 16 positive patients. Our metaanalysis revealed that cervical cancer patiensts infected with HPV 18 had worse PFS compared with those infected with HPV 16 (HR, 1.34; 95\% CI $=1.06-1.70 ; P=$ 0.01, Fig. 6).

\section{Publication bias}

No evidence of publication bias was found in our study by funnel plot, Egger's test $(P>0.05)$ and Begg's test $(P>0.05)$.

\section{Discussion}

Our study was the first systematic review and meta analysis investigating the impact of HPV 16 and HPV 18 on survival in cervical cancer patients. Our results indicated that patients infected with HPV 18 had worse DFS, PFS and OS compared with cervical cancer patients without HPV 18 infection. While the infection of HPV 16 had no impact on survival in cervical cancer patients compared with all other patients. Cervical cancer patients with HPV 18 infection had worse OS in comparision with patients with HPV 16 infection.

An ongoing HPV infection could be a risk factor of infection of another HPV genotype [23, 24] and infection of multiple genotypes of HPV could be a risk factor of persistent infection $[25,26]$, which is foundermental in development of cervical leisions into cervical cancer. Previous study of 43 cervical cancer patients found that an infection of HPV 18 could be related to lack of treatment response [27]. However, previous published studies regarding the unfavorable prognosis of HPV genotypes did not reach consistency.

During the development and progression of cervical cancer, patients could be infected with many genotypes of HPV, including high, intermediate and low risk HPV. However, more publications indicating the negative impact of HPV 16 or HPV 18 on survival in cervical cancer patients $[28,29]$. These studies suggested that HPV to be a prognostic indicator for survival in cervical cancer patients and is of significance identifying specific therapies against HPVharboring cervical cancer patients. However, some of these studies had only small sample size and did not adjust the prognostic relavance of HPV 16 or HPV

\begin{tabular}{|c|c|c|c|c|c|c|}
\hline Study or Subgroup & log[Odds Ratio] & SE & Weight & $\begin{array}{l}\text { Odds Ratio } \\
\text { IV. Fixed, } 95 \% \mathrm{CI}\end{array}$ & $\begin{array}{l}\text { Odds } \\
\text { IV, Fixed }\end{array}$ & $\begin{array}{l}\text { Ratio } \\
\text { d. } 95 \% \mathrm{Cl}\end{array}$ \\
\hline Chyong-Huey Lai 2007 & 0.5254 & 0.2194 & $37.5 \%$ & $1.69[1.10,2.60]$ & & -1 \\
\hline Robert A. Burger 1996 & 0.9517 & 0.4463 & $9.1 \%$ & $2.59[1.08,6.21]$ & & \\
\hline Shizhou Wang 2012 & 0.533 & 0.2256 & $35.5 \%$ & $1.70[1.10,2.65]$ & & $\rightarrow-$ \\
\hline Yat Ming Lau 2015 & 0.207 & 0.3176 & $17.9 \%$ & $1.23[0.66,2.29]$ & & \\
\hline Total $(95 \% \mathrm{Cl})$ & & & $100.0 \%$ & $1.66[1.28,2.17]$ & & 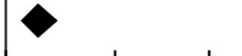 \\
\hline \multicolumn{4}{|c|}{$\begin{array}{l}\text { Heterogeneity: } \mathrm{Chi}^{2}=1.90, \mathrm{df}=3(P=0.59) ; l^{2}=0 \% \\
\text { Test for overall effect: } Z=3.79(P=0.0001)\end{array}$} & & $\begin{array}{lll}0.05 & 0.2 & 1 \\
\text { Favours HPV18+ }\end{array}$ & $\begin{array}{ccc}1 & 5 & 20 \\
\text { Favours HPV18- }\end{array}$ \\
\hline
\end{tabular}




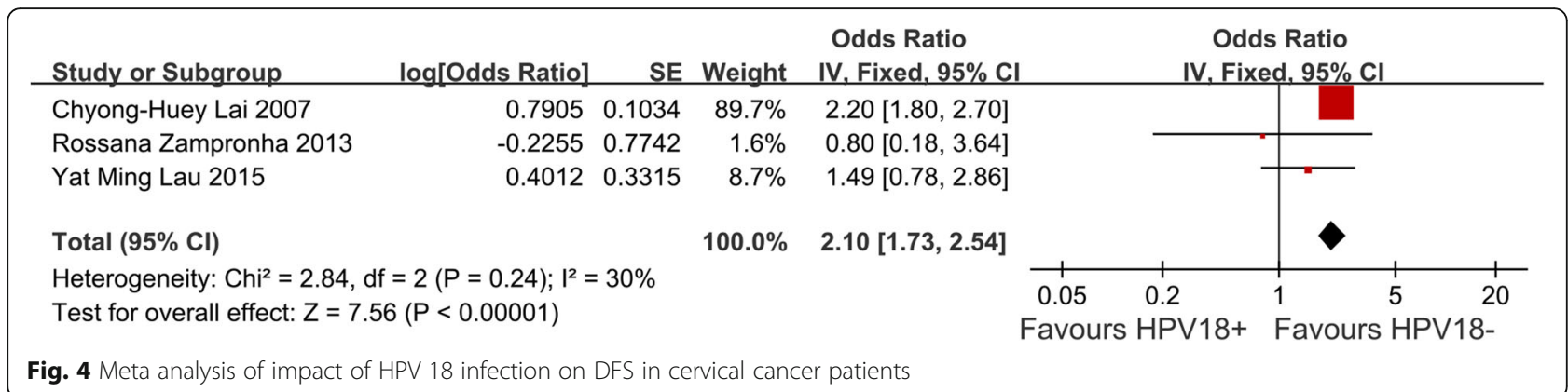

18 using a multivariate cox regression model. Also, studies did not reach consistency as several studies found that HPV 16 or HPV 18 did not have impact on survival. Our study summarizd all the published articles about the HPV 16 and HPV 18 as a prognostic parameter for survival in cervical cancer patients and found that only HPV 18 was negatively associated with survival (OS: $\mathrm{HR}, 1.66 ; 95 \% \mathrm{CI}=$ 1.28-2.17; $P=0.0001$, Fig. 3; DFS: HR, 2.10; $95 \%$ $\mathrm{CI}=1.73-2.54 ; P<0.0001$, Fig. 4 ; PFS: HR, 2.97; $95 \%$ $\mathrm{CI}=1.69-5.23 ; \quad P=0.00012$, Fig. 5). Patients with HPV 18 infection had worse OS compared with patients with HPV 16 infection (HR, 1.34; 95\% CI = 1.06-1.70; $P=0.01$, Fig. 6).

Awareness of the HPV 16 or 18 infection should be raised when it can be controlled during the disease progression. However, for HPV infection, that is not the case. There is no specific medicines to treat HPV infection. The good news is that patients' immune system could clear $90 \%$ of the HPV infection within 2 years, as long as people with normal immunity [30]. For these patients infected with high risk HPV, the immune function is important for cervical carcinogenesis [31]. Chronic stromal inflammation and immune deviation may eventually determine the progression of cervical cancer [31]. Understanding the mechanisms of the HPV infections may help to define new tools for better treatment required to efficiently combat cervical cancer.
We must admit that our meta analysis has several limitations. Firstly, some of the studies recruited in our meta analysis did not have a large sample size, which would ruin the power of statistics. Secondly, the prognostic relavance of HPV 16 or 18 in some studies are not validated using a multivariate analysis considering the impact of confounding factors, such as tumor size, clinical stage and metastasis. Thirdly, these studies recruited a broad spectrum of patients, range from stage I to stage IV patients, which could raise the heterogeneity of the meta analysis. We were not able to get more data about patients with multiple infection of HPV genotypes, such as treatment. Treatment has an impact on the HPV infection, for example, HPV 18 is more resistant to radiotherapy. There are not many studies published comparing the survival relevance of HPV 16 to HPV 18, thus we were not able to make subgroup analyses based on different treatment, such as adjuvant chemotherapy or radiotherapy. We summarized the treatment methods in Table 1 to Table 3 and all the studies recruited in Table 3 using the adjuvant radiation, thus it is not necessary to make subgroup analysis for meta analysis of impact of HPV 16 in comparision with HPV 18 in cervical cancer patients. In addition, our study was the first to gain the importance of recognizing the HPV infection during disease progress and raised the awareness of its prognostic relevance. Large scale

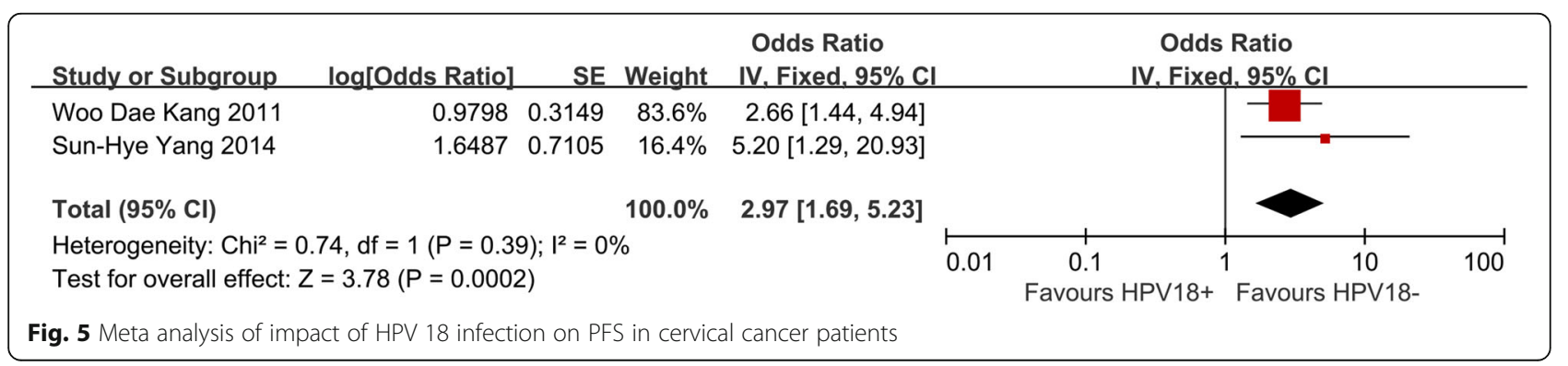




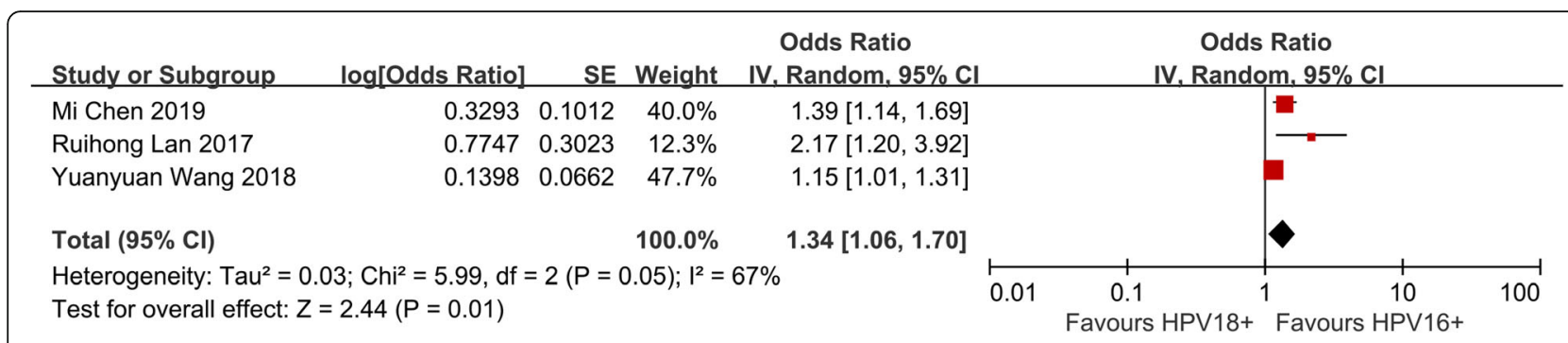

Fig. 6 Meta analysis of impact of HPV 18 in comparision with HPV 16 infection on OS in cervical cancer patients

clinical trials evaluating the impact of HPV 18 versus HPV 16 on survival in cervical cancer patients in different disease stages under various treatment methods such as adjuvant chemotherapy or radiotherapy are needed.

\section{Conclusion}

Cervical cancer patients infected with HPV 18 had worse survival in comparision to patients with HPV 16 infection.

\section{Acknowledgements}

Thanks to the help of the members of West China Second University Hospital, Sichuan University.

\section{Authors' contributions}

Hongjing Wang designed the study, Yuanyuan Xu and Yichao Qiu collected the data, Shuang Yuan did the data analysis. Yuanyuan Xu wrote the first version of manuscript. All the other authors revised and approved the manuscript.

\section{Funding}

Not applicable.

\section{Availability of data and materials}

Data are available from the corresponding author on reasonable request.

\section{Ethics approval and consent to participate}

Not applicable.

\section{Consent for publication}

Not applicable.

\section{Competing interests}

None.

\section{Author details \\ 'Department of Obstetrics and Gynecology, West China Second Key Laboratory of Birth Defects and Related Diseases of Women and Children (Sichuan University), Ministry of Education, West China Second University Hospital, Sichuan University, Chengdu, China. ${ }^{2}$ Department of Obstetrics and Gynecology, West China Second University Hospital, Sichuan University, No.20, Section 3, South People's Road, Chengdu, Sichuan, P.R. China.}

Received: 28 August 2020 Accepted: 26 October 2020

Published online: 07 November 2020

\section{References}

1. Waggoner SE. Cervical cancer. Lancet (London, England). 2003;361(9376): 2217-25.

2. Cancer in Germany 2011/2012. 10th edition Robert Koch Institute (ed) and the Association of Population-based Cancer Registries in Germany (ed) Berlin, 2016
3. Kaliff M, Sorbe B, Mordhorst LB, Helenius G, Karlsson MG, Lillsunde-Larsson G. Findings of multiple HPV genotypes in cervical carcinoma are associated with poor cancer-specific survival in a Swedish cohort of cervical cancer primarily treated with radiotherapy. Oncotarget. 2018;9(27):18786-96.

4. Lau YM, Cheung TH, Yeo W, Mo F, Yu MY, Lee KM, Ho WC, Yeung AC, Law PT, Chan PK. Prognostic implication of human papillomavirus types and species in cervical cancer patients undergoing primary treatment. PLoS One. 2015;10(4):e0122557

5. Hang D, Jia M, Ma H, Zhou J, Feng X, Lyu Z, Yin J, Cui H, Yin Y, Jin G, et al. Independent prognostic role of human papillomavirus genotype in cervical cancer. BMC Infect Dis. 2017;17(1):391.

6. Kim BH, Chang JH. Differential effect of GLUT1 overexpression on survival and tumor immune microenvironment of human papilloma virus type 16positive and -negative cervical cancer. Sci Rep. 2019;9(1):13301.

7. Onuki M, Matsumoto K, Tenjimbayashi Y, Tasaka N, Akiyama A, Sakurai M, Minaguchi T, Oki A, Satoh T, Yoshikawa H. Human papillomavirus genotype and prognosis of cervical cancer: Favorable survival of patients with HPV16-positive tumors. Papillomavirus research (Amsterdam, Netherlands). 2018:6:41-5.

8. Yang SH, Kong SK, Lee SH, Lim SY, Park CY. Human papillomavirus 18 as a poor prognostic factor in stage I-IIA cervical cancer following primary surgical treatment. Obstet Gynecol Sci. 2014;57(6):492-500.

9. Zampronha Rde A, Freitas-Junior R, Murta EF, Michelin MA, Barbaresco AA Adad SJ, Oliveira AM, Rassi AB, Oton GJ. Human papillomavirus types 16 and 18 and the prognosis of patients with stage I cervical cancer. Clinics (Sao Paulo, Brazil). 2013;68(6):809-14.

10. Burger RA, Monk BJ, Kurosaki T, Anton-Culver H, Vasilev SA, Berman ML, Wilczynski SP. Human papillomavirus type 18: association with poor prognosis in early stage cervical cancer. J Natl Cancer Inst. 1996;88(19): $1361-8$.

11. Lai CH, Chang CJ, Huang HJ, Hsueh S, Chao A, Yang JE, Lin CT, Huang SL, Hong $\mathrm{JH}$, Chou $\mathrm{HH}$, et al. Role of human papillomavirus genotype in prognosis of early-stage cervical cancer undergoing primary surgery. J Clin Oncol. 2007:25(24):3628-34.

12. Kang WD, Kim CH, Cho MK, Kim JW, Cho HY, Kim YH, Choi HS, Kim SM. HPV-18 is a poor prognostic factor, unlike the HPV viral load, in patients with stage IB-IIA cervical cancer undergoing radical hysterectomy. Gynecol Oncol. 2011;121(3):546-50.

13. Wang S, Wei H, Wang N, Zhang S, Zhang Y, Ruan Q, Jiang W, Xiao Q, Luan $X$, Qian $X$, et al. The prevalence and role of human papillomavirus genotypes in primary cervical screening in the northeast of China. BMC Cancer. 2012;12:160.

14. Onuki M, Matsumoto K, Satoh T, Oki A, Okada S, Minaguchi T, Ochi H, Nakao S, Someya K, Yamada N, et al. Human papillomavirus infections among Japanese women: age-related prevalence and type-specific risk for cervical cancer. Cancer Sci. 2009;100(7):1312-6.

15. Matsumoto K, Oki A, Furuta R, Maeda H, Yasugi T, Takatsuka N, Mitsuhashi A, Fujii T, Hirai Y, Iwasaka T, et al. Predicting the progression of cervical precursor lesions by human papillomavirus genotyping: a prospective cohort study. Int J Cancer. 2011;128(12):2898-910.

16. Muñoz N, Bosch FX, de Sanjosé S, Herrero R, Castellsagué X, Shah KV, Snijders PJ, Meijer CJ. Epidemiologic classification of human papillomavirus types associated with cervical cancer. N Engl J Med. 2003;348(6):518-27.

17. Cogliano V, Baan R, Straif K, Grosse Y, Secretan B, El Ghissassi F. Carcinogenicity of human papillomaviruses. Lancet Oncol. 2005;6(4):204.

18. Wright JD, Li J, Gerhard DS, Zhang Z, Huettner PC, Powell MA, Gibb RK, Herzog TJ, Mutch DG, Trinkaus KM, et al. Human papillomavirus type and 
tobacco use as predictors of survival in early stage cervical carcinoma. Gynecol Oncol. 2005;98(1):84-91.

19. Chien TJ, Hsu CH, Liu CY, Fang CJ. Effect of acupuncture on hot flush and menopause symptoms in breast cancer- a systematic review and metaanalysis. PLoS One. 2017;12(8):e0180918.

20. Lan Ruihong GH. Expression and clinical significance of HPV16, 18E6 and p53 in cerviacal carcinoma. Chin J Health Care Med Chin J Health Care Med. 2017:6(19):239-41.

21. Wang YDX, Hu X. Analysis of the changes of HPV16/18 infection and Ki 67 and P16INK4a expression in cervical cancer and cervical intraepithelial neoplasia. Modern Med Health Res 2018. 2018;2:4.

22. Mi C. Expression Levels and Clinical Significance of HPV16 $18 \mathrm{E} 6$ and p53 in Cervical Cancer Patients. Pract J Cancer. 2019;34(8):1267i-1270.

23. Mendez F, Munoz N, Posso H, Molano M, Moreno V, van den Brule AJ, Ronderos M, Meijer C, Munoz A. Cervical coinfection with human papillomavirus (HPV) types and possible implications for the prevention of cervical cancer by HPV vaccines. J Infect Dis. 2005;192(7):1158-65.

24. Rousseau MC, Pereira JS, Prado JC, Villa LL, Rohan TE, Franco EL. Cervical coinfection with human papillomavirus (HPV) types as a predictor of acquisition and persistence of HPV infection. J Infect Dis. 2001;184(12): 1508-17.

25. Schmeink CE, Melchers WJ, Siebers AG, Quint WG, Massuger LF, Bekkers RL Human papillomavirus persistence in young unscreened women, a prospective cohort study. PLoS One. 2011;6(11):e27937.

26. Gradissimo A, Lam J, Attonito JD, Palefsky J, Massad LS, Xie X, Eltoum IE, Rahangdale L, Fischl MA, Anastos K, et al. Methylation of high-risk human papillomavirus genomes are associated with cervical Precancer in HIVpositive women. Cancer Epidemiol Biomarkers Prev. 2018;27(12):1407-15.

27. Munagala R, Donà MG, Rai SN, Jenson AB, Bala N, Ghim SJ, Gupta RC. Significance of multiple HPV infection in cervical cancer patients and its impact on treatment response. Int J Oncol. 2009;34(1):263-71.

28. Pilch $H$, Günzel $S$, Schäffer $U$, Tanner B, Brockerhoff $P$, Maeurer $M$, Höckel $M$, Hommel G, Knapstein PG. The presence of HPV DNA in cervical cancer: correlation with clinico-pathologic parameters and prognostic significance: 10 years experience at the Department of Obstetrics and Gynecology of the Mainz University. Int J Gynecol Cancer. 2001;11(1):39-48.

29. Lombard I, Vincent-Salomon A, Validire P, Zafrani B, de la Rochefordière A, Clough K, Favre M, Pouillart P, Sastre-Garau X. Human papillomavirus genotype as a major determinant of the course of cervical cancer. J Clin Oncol. 1998;16(8):2613-9.

30. Best SR, Niparko KJ, Pai SI. Biology of human papillomavirus infection and immune therapy for HPV-related head and neck cancers. Otolaryngol Clin N Am. 2012;45(4):807-22.

31. Smola S. Immune deviation and cervical carcinogenesis. Papillomavirus research (Amsterdam, Netherlands). 2019;7:164-7.

\section{Publisher's Note}

Springer Nature remains neutral with regard to jurisdictional claims in published maps and institutional affiliations.

Ready to submit your research? Choose BMC and benefit from:

- fast, convenient online submission

- thorough peer review by experienced researchers in your field

- rapid publication on acceptance

- support for research data, including large and complex data types

- gold Open Access which fosters wider collaboration and increased citations

- maximum visibility for your research: over $100 \mathrm{M}$ website views per year

At $\mathrm{BMC}$, research is always in progress.

Learn more biomedcentral.com/submissions 